\title{
Causes of Delay in MARA Management Procurement Construction Projects
}

\author{
Mohd Razaki Abdullah ${ }^{1}$, Ismail Abdul Rahman², Ade Asmi Abdul Azis ${ }^{3}$, \\ Faculty of Civil and Environmental Engineering \\ Universiti Tun Hussein Onn Malaysia \\ 1'mrazaki@mail.mara.gov.my, \\ ismailar@uthm.edu.my, ${ }^{3}$ ade@uthm.edu.my.
}

\begin{abstract}
For many years, the issue of delay in MARA management procurement construction projects has been phenomenal. Its impacts were so significant that it tends to decelerate the implementation of MARA strategic planning. This paper presents a survey study on significant causes of delay in MARA management procurement construction projects. The questionnaire used consists of identified 18 causes of delay. The study was carried out on the current $12(38.7 \%)$ MARA construction management procurement projects scattered in peninsular Malaysia. The respondents were personnel that work as PMC (executives, resident engineers, and clerk of works) for those projects and clients (MARA state directors, project officers, and engineers). Seventy sets of questionnaire were distributed to the respondents and 58 sets $(82.86 \%)$ returned. The results analysis revealed that the significant delay causes were cash flow and financial difficulties faced by contractors, contractors' poor site management and ineffective planning and scheduling by contractors. Several steps are proposed in order to avoid delay for MARA future project.
\end{abstract}

Key words: Construction delay, MARA construction projects, Majlis Amanah Rakyat

\section{Introduction}

MARA (Majlis Amanah Rakyat) is one of the government agencies that plays important role in implementing the government policy. It was formed on March 1, $\underline{1966}$ under the Rural and National Development Ministry and its core business is to aid, train, and guide Bumiputeras (Malays and other indigenous Malaysians) in the areas of business and industry [22]. In implementing the government policy, MARA is indirectly involved in construction industry. Unfortunately, more than $90 \%$ of its Management procurement projects ended up delayed. Therefore the objective of this study is to identify its significant cause of delay from the perspective of client and PMC. 
Approximately RM 12 billion was spent by MARA in its development for the period of $1^{\text {st }}-8^{\text {th }}$ Malaysian plan [1] and a big portion of this allocation was spent on construction. MARA has its own construction unit, Construction and maintenance unit (UBS) to manage the small projects but normally engage PMC services for its large and complex construction project.

Management procurement was introduced in MARA since 1980s and was extensively applied in the 1990s. Currently this method is still used with slight modification. Basically, 'contract management' variation is used where the contractor's contract is with MARA and leaving the manager or PMC with virtually no risk. Figure 1.0 and 2.0 show the contractual relationship and sequence of operation of MARA management procurement.

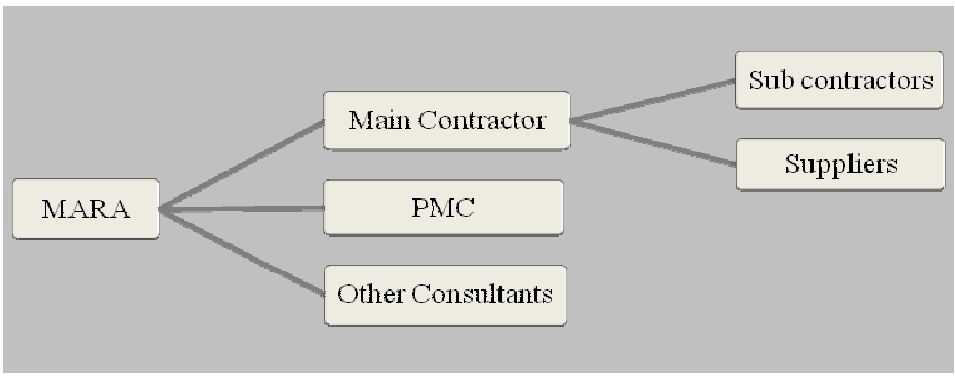

Figure 1.0 Contractual Relationship of MARA Management Procurement

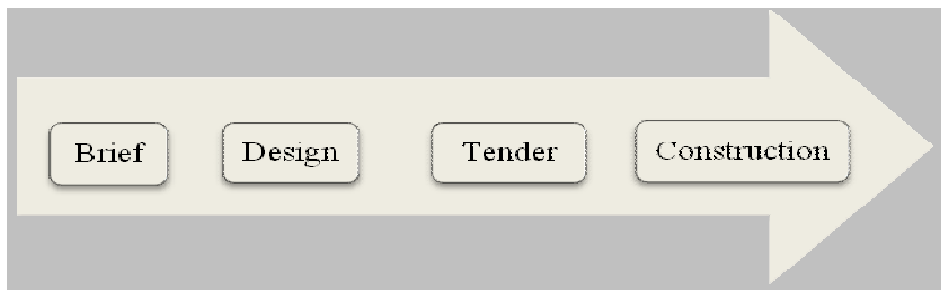

Figure 2.0 Sequence of Operation of MARA Management Procurement

Based on figure 1.0, it is clearly shown that MARA has direct contract with Main Contractor, PMC and Other consultants while sub-contractors and material suppliers have contractual relationship with main contractor. In the sequence of operation as shown in figure 2.0, the first operation is project brief to PMC/Designer by MARA, then design by designers, follow by tendering process and finally constructing. 
Construction delays can be defined in many ways. [2] relates construction delay to progress compared to baseline construction schedule while [3],[4] and [5] summarized that a delay is when there is time overrun or extension of time to complete the project. Therefore a delay is a situation when the actual progress of a construction project is slower than the planned schedule or late completion of the projects.

The construction delay can be grouped into three types [6]; $\boldsymbol{i}$. excusable delays. This delay is due to causes of delay beyond the contractor's control such as unforeseen events and also no fault or negligence in contractor's part. It can be divided into compensable or non compensable. The compensable delay is the delay caused by client or designer (architect or engineer) such as design errors and changes in client's requirements. On the other hand, non compensable delay is the delays that are not caused by client, designer, contractor, subcontractor, supplier or other parties [19]. Adverse weather, differing site conditions, unavoidable calamities, acts of God and unusual delays in transportation are few examples of non compensable delay. For compensable delay, a contractor is entitled both additional time and compensation, but for non compensable delay, a contractor is entitled to extension of time only. Normally the compensation given to contractor is in the form of variable orders (VO). ii. Non excusable delays. In contrast to excusable delay, a non excusable delay is delay due to contractor's weaknesses or not caused by the contractor but should be anticipated by the contractor under normal condition [3]. Besides that, non excusable delay provides no bases for recovery of either the time or the monetary impact of the delay [20]. The contractor is the sole responsible party and consequently, they are not entitled to either extension of time or compensation. However the client could be entitled to claim liquidated damages from the contractor. The cause of delay such as late in material procurement, financial difficulties faced by contractors, ineffective planning and scheduling, change management and problems with sub contractors are a few examples of non excusable delay. iii. Concurrent delays. This delay is due to the combination of two or more independent causes of delay during the same period [3]. [21] added that this delay occurs, at least to some degree, during the same period of time. Most of the time, this delay involves excusable and non excusable delay. Therefore this delay may lead to disputes between contractor and client. The contractor only entitled to extension of time or compensation for the excusable delay but the penalty or liquidated damages for the non excusable delay. 
Extensive research works on construction delay had been carried-out throughout the world. [7] studied on high-rise building construction projects in Bangkok and identified 26 causes of construction delay. Their findings concluded that only three causes are considered significant. In Hong Kong, [8] conducted a comparative study of causes of time overruns in construction projects and found five principal causes of delays. In Saudi Arabia, 37\% of constructions in public utility projects were delayed and $87 \%$ were approved extension of time as has been concluded by [9], beside that they also concluded eight major factors that contributed to the delay. While in Jordan, [10] revealed in their study that contractors and consultants agreed that owner interference, inadequate contractors experience, financing and payments and labour productivity are significant factors of construction delay of large construction project that adopted traditional contracts approach. For groundwater project in Ghana, [11] illustrated that owners, contractors and consultants ranked poor contractor management, monthly payment difficulties from agencies, material procurement, poor technical performances and escalation of material prices as major factors that can cause time overrun. [12] identified 62 causes of delay where five causes were classified as significant to the construction delay of large construction project in Vietnam. [16] surveyed causes of delay in Saudi Arabia large construction projects. The study established that $70 \%$ of projects experienced time overrun and identified six main causes for the delay. Improper site co-ordination and management of the electrical and mechanical installations, lack of timely decision making of the client, and defects identified during the fire service inspection by local authorities were the significant delay factors of fire services installation permit on time in Hong Kong [13]. In Malaysia, studied that carried out by [14] found ten main causes of construction delay. In residential projects construction in Jordan, the main cause of delays were financial difficulties faced by the contractors, too many change orders by the owner and poor planning and scheduling of the project by the contractors [15]. The summaries of findings from the previous studies by the above researchers are tabulated based on the dates in chronological order in Table 1. This table explicitly shows the significant causes of construction delay as found by the past researchers. 
Table 1: Summary of findings of Significant Cause of Construction Delay

\begin{tabular}{|c|c|c|c|c|}
\hline \multirow[b]{2}{*}{ No. } & \multirow[b]{2}{*}{ Researchers } & \multirow[b]{2}{*}{$\begin{array}{l}\text { Project - } \\
\text { Country }\end{array}$} & \multicolumn{2}{|c|}{ Findings on Causes of Construction Delay } \\
\hline & & & $\begin{array}{c}\text { Numbers } \\
\text { of } \\
\text { Causes } \\
\text { Identified }\end{array}$ & Significant Causes Identified \\
\hline 1 & {$[7]$} & $\begin{array}{l}\text { Construction } \\
\text { delay of high- } \\
\text { rise building } \\
\text { construction } \\
\text { project in } \\
\text { Bangkok, } \\
\text { Thailand }\end{array}$ & 26 & $\begin{array}{l}\text { - Shortages of construction } \\
\text { materials. } \\
\text { - Shortage of site workers } \\
\text { - Frequent changes by owners. }\end{array}$ \\
\hline 2 & {$[8]$} & $\begin{array}{l}\text { Causes of time } \\
\text { overrun in } \\
\text { construction } \\
\text { projects in } \\
\text { Hong Kong }\end{array}$ & 20 & $\begin{array}{l}\cdot \text { Poor site management } \\
\text { Unforeseen ground condition } \\
\text { Low speed of decision making } \\
\text { - Client-initiated variation } \\
\text { Necessary variations of works }\end{array}$ \\
\hline 3 & [9] & $\begin{array}{l}\text { Delay in } \\
\text { public utility } \\
\text { projects in } \\
\text { Saudi Arabia }\end{array}$ & $\begin{array}{c}\text { Not } \\
\text { mentioned }\end{array}$ & $\begin{array}{l}\text { - Cash flow and financial } \\
\text { difficulties } \\
\text { - Difficulties in getting work } \\
\text { permit } \\
\text { - Practice of assigning contract } \\
\text { to lowest bidder • Underestimate } \\
\text { project duration } \\
\text { - Effect of sub-surface condition } \\
\text { - Changes in scope of projects } \\
\text { - Ineffective planning and } \\
\text { scheduling by contractors } \\
\text { Shortage of manpower }\end{array}$ \\
\hline
\end{tabular}


Table 1: Summary of findings of Significant Causes of Construction Delay (continued)

\begin{tabular}{|c|c|c|c|c|}
\hline \multirow[b]{2}{*}{ No. } & \multirow[b]{2}{*}{ Researchers } & \multirow[b]{2}{*}{$\begin{array}{l}\text { Project - } \\
\text { Country }\end{array}$} & \multicolumn{2}{|c|}{ Findings on Causes of Construction Delay } \\
\hline & & & $\begin{array}{c}\text { Numbers } \\
\text { of } \\
\text { Causes } \\
\text { Identified }\end{array}$ & Significant Causes Identified \\
\hline 4 & {$[10]$} & $\begin{array}{l}\text { Causes of } \\
\text { construction } \\
\text { delay : } \\
\text { traditional } \\
\text { contracts of } \\
\text { large } \\
\text { construction } \\
\text { industry in } \\
\text { Jordan }\end{array}$ & 28 & $\begin{array}{l}- \text { Inadequate contractor } \\
\text { experience. } \\
\text { - Owner interference } \bullet \text { Finance } \\
\text { and payments of completed } \\
\text { work } \bullet \text { Slow decision making by } \\
\text { owners } \bullet \text { Labor productivity }\end{array}$ \\
\hline 5 & {$[11]$} & $\begin{array}{l}\text { Causes of delay } \\
\text { and cost } \\
\text { overruns in } \\
\text { construction of } \\
\text { groundwater } \\
\text { projects in } \\
\text { Ghana }\end{array}$ & 26 & $\begin{array}{l}\bullet \text { Monthly payment difficulties } \bullet \\
\text { Poor contractor management. } \\
\text { Material procurement } \bullet \text { Poor } \\
\text { technical performances } \\
\text { - Escalation of material prices }\end{array}$ \\
\hline 6 & {$[12]$} & $\begin{array}{l}\text { The delay of } \\
\text { large } \\
\text { construction } \\
\text { project in } \\
\text { Vietnam }\end{array}$ & 62 & $\begin{array}{l}\text { - Incompetent designers and } \\
\text { contractors. } \\
\text { - Poor estimation and change } \\
\text { management. } \\
\text { - Social and technological issues. } \\
\text { - Site related issues. - Improper } \\
\text { techniques and tools. }\end{array}$ \\
\hline 7 & {$[16]$} & $\begin{array}{l}\text { causes of delay } \\
\text { in large } \\
\text { construction } \\
\text { projects in } \\
\text { Saudi Arabia }\end{array}$ & 56 & $\begin{array}{l}\text { - Change order } \bullet \text { Delay in } \\
\text { progress payment } \\
\text { - Ineffective planning and } \\
\text { scheduling of project by } \\
\text { contractor } \bullet \text { Poor site } \\
\text { management and supervision by } \\
\text { contractor } \bullet \text { Shortage of labors } \\
\text { Difficulties in financing project } \\
\text { by contractor }\end{array}$ \\
\hline 8 & {$[13]$} & $\begin{array}{l}\text { Fire services } \\
\text { installation } \\
\text { related } \\
\text { contributors of } \\
\text { construction } \\
\text { delays in Hong } \\
\text { Kong building } \\
\text { construction } \\
\text { work }\end{array}$ & 49 & $\begin{array}{l}\text { - Improper site co-ordination and } \\
\text { management of the electrical and } \\
\text { mechanical installation. } \\
\text { - Lack of timely decision } \\
\text { making of the client } \bullet \text { defects } \\
\text { identified during the fire services } \\
\text { inspection }\end{array}$ \\
\hline
\end{tabular}




\begin{tabular}{|c|c|c|c|c|}
\hline 9 & [14] & $\begin{array}{l}\text { Causes and } \\
\text { effects of } \\
\text { delays in } \\
\text { Malaysian } \\
\text { construction } \\
\text { industry. }\end{array}$ & 28 & $\begin{array}{l}\text { - Contractor's improper } \\
\text { planning. } \\
\text { •Contractor's poor site } \\
\text { management. } \\
\text { - Inadequate contractor } \\
\text { experience } \\
\text { - Inadequate client's finance and } \\
\text { payments for completed work } \\
\text { Problems with subcontractors • } \\
\text { Shortage in materials } \cdot \text { Labor } \\
\text { supply } \\
\text { - Equipment availability and } \\
\text { failure } \\
\text { - Lack of communication } \\
\text { between parties } \\
\text { - Mistakes during the } \\
\text { construction stage }\end{array}$ \\
\hline 10 & [15] & $\begin{array}{l}\text { Delays in } \\
\text { construction } \\
\text { projects: The } \\
\text { case of Jordan }\end{array}$ & 40 & $\begin{array}{l}\text { - Financial difficulties faced by } \\
\text { contractor } \\
\text { - Too many change orders by } \\
\text { owner } \\
\text { - Poor planning and scheduling } \\
\text { of the project by contractor. }\end{array}$ \\
\hline
\end{tabular}

Based on the significant causes of delay as in Table 1, many countries shared common cause of delay although they are not in the same region. The frequent changes by owners and inadequate client's finance and payments for completed work seems to be the most frequent major cause of delay where 5/10 researchers specify this. The shortage of site workers, ineffective planning and scheduling by contractors and contractors poor site management seem to be the $2^{\text {nd }}$ most frequent major cause of delay where $4 / 10$ researchers concluded in their study. The $3^{\text {rd }}$ frequent major cause of delay from this study are cash flow and financial difficulties faced by contractors, unforeseen ground condition and low speed of decision making. The $4^{\text {th }}$ frequent $(2 / 10)$ major cause of delay were shortages of construction materials and inadequate contractor experience and the least frequent (1/10) major cause of delay were client-initiated variation, necessary variations of works, difficulties in getting work permit, practice of assigning contract to lowest bidder, underestimate project duration, changes in scope of projects, owner interference, labour productivity, material procurement, poor technical performances, escalation of material prices, incompetent designers and contractors, poor estimation and change management, social and technological issues, improper 
techniques and tools, improper site co-ordination and management of the electrical and mechanical installation, defects identified during the fire services inspection, problems with subcontractors ,equipment availability and failure, lack of communication between parties, and mistakes during the construction stage. Countries such as Saudi Arabia, Jordan, Ghana and Malaysia seem to share some common major cause of delay although they are not in the same region. The most significant issue faced by these countries is cash flow and financial difficulties faced either by the owners or contractors. Some of the major cause of delays is unique where it is applicable to a particular project or country only.

\section{Methodology}

In order to address the hypotheses that come from theory, a specialized set of methods are required. Quantitative methods attempt to add to the universal knowledge of society [23] where these methods have been used to produce "real answers" from "hard data". On the other hand, qualitative methods are not good at giving direct answers, but are good at developing more questions. This occurs because qualitative methods are consistently using "soft data"[24]. As the objective of this study is to gather the real and direct answers, the quantitative method is preferred.

A survey questionnaire was developed to determine the perception of client and PMC on the significant causes of delay in MARA management procurement construction projects. The questionnaire was divided into 2 parts;

\section{i. Demography,}

This part contains questions on background information of respondents such as gender, age, highest education, occupational level, years of working experience, field of specialization, and largest project involved based on contract sum

\section{ii. Significant causes of delay,}

This part contains 18 well recognized significant causes of delay identified through secondary data and preliminary analysis. At the end of the questionnaire, there is an open ended question for any added information. 
A five point likert-scale of 1 to 5 was adopted to assess the degree of agreement of each cause where 1 represent 'strongly disagree', 2 'disagree', 3 'moderately agree', 4 'agree' and 5 'strongly agree'. Sensitive issues such as political and religious issues were omitted to avoid the prejudice response. Before distributing the questionnaire, the questionnaire was tested for its validity and sufficiency. The validity was tested by referring to 4 experts [a MARA director, a consultant engineer, a CIDB state director, and a class A contractor] who are familiar and have more than 25 years experience with Malaysia construction industry or used to work on MARA projects. The sufficiency test was carried out through pilot study.

A 'cluster sampling' was used in this study where 12 construction sites $(38.7 \%)$ divided into 4 zones scattered throughout peninsular Malaysia were selected as samples. The respondents for clients were MARA state directors, MARA division project officers, and MARA UBS engineers who were directly involve with MARA construction projects, while the respondents for PMC were executives, resident engineers and clerk of works for that selected projects. The author visited and distributed the questionnaire to the respondents at the sites by hand (face to face method) and self collect it. Some of the questionnaire was sent by email, mail and through third parties and followed up by phone. Discussion also had been carried out with some of the respondents to clarify certain issues and giving more freedom for the respondents to air their views. Altogether from 70 sets of questionnaires distributed, 58(82.86\%) responded. The data were analyzed by using SPSS version 17.0 software and tested for its reliability and level of agreement of the ranked scores.

\section{Discussion On The Findings}

The validity test shows that all experts agreed that $90.28 \%$ of the questions in the questionnaire were highly relevant and adequate for the purpose of achieving the objective of the study. The pilot study shows that all respondents agreed that the questionnaire is sufficient to determine the significant causes of the construction delay, therefore no change has been done to the questionnaire. In the data reliability test, Cronbach's Alpha value was $0.674(\alpha>0.6)$ which shows that the data is acceptable [16]. The value of the Kendall's Coefficient of Concordance was 0.294 ( $W \geq 0)$ which 
shows that the level of agreement of the ranked scores is quite significant [17]. The demography of the respondents is shown in Table 2, the ranking analysis is shown in Table 3, and the correlation analysis is shown in Table 4.

In the demography analysis in Table 2 shows that $96.6 \%$ of the respondents were male, $74.25 \%$ were $30-49$ years old, the majority of the respondents $(67.2 \%)$ had tertiary education, $75.9 \%$ has experience more than 10 years, $69 \%$ has specialization in building and $81 \%$ of the respondents involved in projects cost more than 50 million ringgits.

The ranking of the causes of delay are based on the mean rank of the data. The higher the mean rank means the more significant the causes are. In this study, the author considers mean rank of 12.6 (mean of 3.5) and above as the selected value for the significant cause of delay. Based on Table 3, the significant causes of delay in MARA management procurement projects are; i. cash flow and financial difficulties faced by contractors (13.03), ii. Contractor's poor site management (12.86) and iii. Ineffective planning and scheduling by contractors (12.66).

The correlation coefficient value of 0.5-1.0 gives have high degree of correlation [18]. Based on Table 4, ineffective planning and scheduling by contractors has high degree of correlation with contractor's poor site management (0.578) and vice-versa. Similarly, frequent design changes have high degree of correlation with changes in scope of projects during construction work (0.612).

\section{The significant causes of delay are as follows;}

\section{i. Cash flow and financial difficulties faced by contractors}

Cash flow and financial difficulties faced by contractors is the most significant cause of MARA management procurement construction delay. An interview with Mr. Halipah K (MARA former UBS Head) revealed that many contractors started work late although the site were handed over earlier to them. They were waiting for loan approval from financial institution before the work could be started. Although there is a provision that contractor may apply for advance payment from the client ( $25 \%$ of contract cost or RM 
10 million (which one is higher)), but unfortunately this provision is ineffective and still fail to resolve this issue. Most of the contractors outsource its works to sub-contractors, the failure for contractor to pay to sub-contractors on time resulting in slowing down the work due to reduce number of workers hired by sub-contractors.

Table 2: Demography of respondents

\begin{tabular}{|c|c|c|c|}
\hline \multirow[b]{2}{*}{ Gender } & $\%$ & \multirow[b]{2}{*}{$\begin{array}{l}\text { Working } \\
\text { experience[years] }\end{array}$} & \multirow[t]{2}{*}{$\%$} \\
\hline & & & \\
\hline Male & 96.6 & $<2$ & 1.7 \\
\hline Female & 3.4 & $2-5$ & 3.4 \\
\hline Age[years] & & $6-10$ & 19 \\
\hline $20-29$ & 5.2 & $>10$ & 75.9 \\
\hline $30-39$ & 39.7 & Field of specialization & \\
\hline $40-49$ & 34.5 & Building & 69 \\
\hline$>50$ & 20.7 & Mechanical & 3.4 \\
\hline Highest education & & Electrical & 5.2 \\
\hline \multirow[t]{2}{*}{ Secondary[form 1-5] } & 12.1 & Others & 22.4 \\
\hline & & Largest project involved & \\
\hline Pre-U[form 6 or & & based on contract & \\
\hline equivalent] & 20.7 & sum/mil RM] & \\
\hline University[dip-degree] & 56.9 & $<1$ & 1.7 \\
\hline Post graduate[master-phd] & 10.3 & $1-10$ & 5.2 \\
\hline Occupational level & & $10-50$ & 12.1 \\
\hline executive & 1.7 & $>50$ & 81 \\
\hline managerial & 56.9 & & \\
\hline Support & 41.4 & & \\
\hline
\end{tabular}


Table 3.0: Ranking of Significant Cause of Delay

\begin{tabular}{|lll|}
\hline \multicolumn{1}{|c}{ Causes of Delay } & Mean & Rank \\
& Rank & \\
\hline Cash flow and financial difficulties faced by & 13.03 & 1 \\
contractors & 12.86 & 2 \\
Contractor's poor site management & 12.66 & 3 \\
Ineffective planning and scheduling by contractors & 12.22 & 4 \\
Inadequate contractor experience & 11.96 & 5 \\
Shortage of site workers & 10.78 & 6 \\
Lack of communication among parties & 10.59 & 7 \\
Escalation of material prices & 10.59 & 8 \\
Problems with subcontractors & 9.95 & 9 \\
Practice of assigning contract to lowest bidder & 9.91 & 10 \\
Change management & 9.16 & 11 \\
Incompetent designers & 8.91 & 12 \\
Late in material procurement & 8.72 & 13 \\
Poor estimate project duration & 6.93 & 14 \\
Low speed of decision making & 6.41 & 15 \\
Unforeseen ground condition & 6.27 & 16 \\
Changes in scope of projects during construction work & 5.36 & 17 \\
Frequent design changes & 4.71 & 18 \\
Owner interference in construction work/process & & \\
& & 16 \\
\hline
\end{tabular}


Table 4: High Correlation of Cause of Delay

\begin{tabular}{|c|c|c|c|c|c|c|c|}
\hline \multirow{5}{*}{ 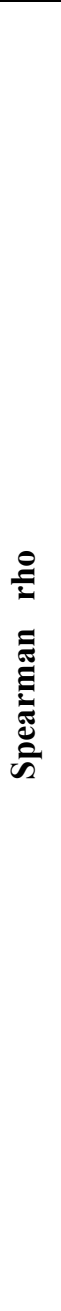 } & & & 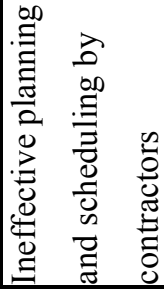 & 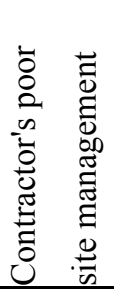 & 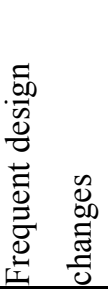 & 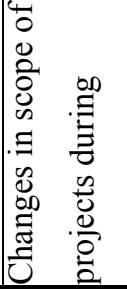 & 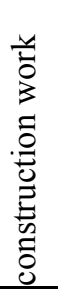 \\
\hline & $\begin{array}{l}\text { Ineffective } \\
\text { planning and } \\
\text { scheduling by } \\
\text { contractors }\end{array}$ & $\begin{array}{l}\text { Correlation } \\
\text { Coefficient } \\
\text { Sig. (2-tailed) } \\
\text { N }\end{array}$ & & $\begin{array}{c}.578^{* *} \\
.000 \\
58\end{array}$ & & & \\
\hline & $\begin{array}{l}\text { Contractor's } \\
\text { poor site } \\
\text { management }\end{array}$ & $\begin{array}{l}\text { Correlation } \\
\text { Coefficient } \\
\text { Sig. (2-tailed) } \\
\text { N }\end{array}$ & $\begin{array}{c}.578^{* *} \\
.000 \\
58\end{array}$ & & & & \\
\hline & $\begin{array}{l}\text { Frequent design } \\
\text { changes }\end{array}$ & $\begin{array}{l}\text { Correlation } \\
\text { Coefficient } \\
\text { Sig. (2-tailed) } \\
\text { N }\end{array}$ & & & & $\begin{array}{c}.612^{*} \\
.000 \\
58\end{array}$ & \\
\hline & $\begin{array}{l}\text { Changes in } \\
\text { scope of projects } \\
\text { during } \\
\text { construction } \\
\text { work }\end{array}$ & $\begin{array}{l}\text { Correlation } \\
\text { Coefficient } \\
\text { Sig. (2-tailed) } \\
\text { N }\end{array}$ & & & $\begin{array}{c}.612^{* *} \\
.000 \\
58\end{array}$ & & \\
\hline
\end{tabular}

** Correlation is significant at the 0.05 level (2-tailed)

\section{ii. Contractor's poor site management}

The site management is the 'engine' of contractor's construction organization where it controls all activities at the site. The failure in managing and attending the daily routine coupled with other problems at the project site contribute to the delay significantly. The incompetent of site managers come with minimum support from the top management worsen the situation. There were cases where the site manager quits for other better job and the post were vacant for quite sometime resulting in poor site management and 
eventually delay in work progress. When a new and inexperienced project manager is hired, he/she takes sometime to adapt to new environment. Based on Table 4, the contractor's poor site management has high degree of correlation with ineffective planning and scheduling by contractors and vice-versa.

\section{iii.Ineffective planning and scheduling by contractors}

Planning and scheduling are extremely important components of project management. It is produced by contractors according to client's requirement and approved by clients. It also serves as guidelines during construction. The inability of contractor to execute work according to the planning and scheduling may lead to delay in work progress and eventually lead to project delay. The shortage of site workers and the fluctuations of material prices are the most common contribution to ineffective planning and scheduling by contractors. The ineffective planning and scheduling by contractors has high degree of correlation with contractor's poor site management and vice-versa. In other word, the changes to ineffective planning and scheduling by contractor have strong linear effect to contractor's poor site management or the other way round.

\section{Conclusion And Recommendation}

It is concluded that the significant causes of MARA management procurement of construction delay are; cash flow and financial difficulties faced by contractors, contractor's poor site management and ineffective planning and scheduling by contractors. The result also concluded that all of the significant causes are contractor related. Therefore this study tends to suggest that MARA should;

I. Give special attention to the financial standing of the contractors. Make sure that the contractors to be considered for future projects can prove that they are financially sound and have a strong backing from financial institution.

II. Validate the curriculum vitae of all of the contractors' site management personnel so that only the qualified, experienced and proven site management team will be considered for the projects.

III. Check and validate the track record of the contractors. The recommendation from authority body such as CIDB is an added advantage. 


\section{References}

Retrieved from http://maranet.mara.gov.my/internet/Korporat/web04_09/Page07.htm. on 0th July 2009

Retrieved from http://en.wikipedia.org/wiki/Construction_delay on 10th July 2009

Mubarak S, Construction Project Scheduling and Control, Pearson Prentice Hall, (2005)

Assaf S.A, Al-Hejji S, Causes of delay in large construction projects. International Journal of Project Management 24 (2006).:349- 357

Stumpf G. (2000). Schedule delay analysis. Cost Eng J 42[7]: 32-43

Bramble B.B., and Callahan M.T, Construction delay claims, $3^{\text {rd }}$ Edition, 1.01A, B, D. New York: Aspen, ( 2000)

Ogunlana S.O , Promkuntong K, Jearkjirm V, Construction delays in a fast- growing economy: comparing Thailand with other economies, International Journal of project management 14 (1996): 37-45

Chan D. W. M. and Kumaraswamy M. M ,A comparative study of causes of time overruns in Hong Kong construction project, International Journal of project management 15(1997) : 55-63

Al-Khalil M and Al-Ghafly M, Important causes of delay in public utility projects in Saudi Arabia, Constr Manage Econ 17 (5), (1999): 647-655.

Odeh A.M and Battaineh H.T, Causes of construction delay: traditional contracts, Int $J$ Project Manage 20 (1) (2002): 67- 73.

Frimpong Y, Oluwoye J , Crawford L, Causes of delay and cost overruns in construction of groundwater projects in a developing countries; Ghana as a case study, International Journal of project management 21,[2003] : 321-326

Long N.D, Ogunlana S , Quang T and Lam K.C, The delay of large construction projects in developing countries: a case study from Vietnam, International Journal of project management 22, (2004): 553-561

Fong N.K, Wong L.Y and Wong L.T, Fire services installation related contributors of construction delays, Building and Environment 41, (2006), 211-222

Sambasivan M, Soon Y.W), Causes and effects of delays in Malaysian construction industry, International Journal of project management 25, (2007): 517-526 
Sweis, G., Sweis, R., Hammad, A.A., and Shboul, A. (2007). "Delays in construction projects: The case of Jordan.” Int. J. Project Management, Article in Press.

Xin, L, Rong, W, School of Economics and Management, Beijing Institute of Petrochemical

and Technology, P.R.China, 102617, School of Economics and Management, Beijing University of Chemical Technology, P.R.China, 100029, ,(2007)

Siegel, S, Nonparametric Statistics for the Behavioral Sciences. New York: McGrawHill

Book Company. .(1956)

Cohen, J. Statistical power analysis for the behavioral sciences (2nd edition). Hillsdale, NJ:

Erlbaum. (1988)

Odeh A.M. and Battaineh H.T., Causes of construction delay: traditional contracts, Int $\mathrm{J}$

Project Manage 20 (1) (2002), pp. 67-73.

Alkass,S, Mazerolle, M., Harris, F.,(1995) Construction Delay Analysis Techniques, School

of Construction, Engineering and Technology, University of Wolverhampton, UK.14, 375-394

Fong, C.K (2004). Law and Practice of Construction Contracts, $3^{\text {rd }}$ ed., Sweet \& Maxwell

Asia, Singapore

MARA (2009), Sejarah MARA dari Risda ke MARA. Retrieved on February 15, 2009 from

http://maranet.mara.gov.my/internet/Am/sejarah mara dari rida ke mara.htm Blalock, H. M. (1979). Social statistics. New York, NY: McGraw Hill.

Higgins, G.E (2009). Quantitative versus Qualitative Methods: Understanding Why Quantitative Methods are Predominant in Criminology and Criminal Justice. Journal of Theoretical and Philosophical Criminology, Vol 1 (1) 2009 